スペイン語の語頭と語内について

阿部三男

0、スペイン語では，一般に語頭子音を強め，語内子音を弱めるといわれ， 特に母音間での無声破裂音の有声化は西ロマンス諸語の一・大音声特街とされ， これに重子音（geminadas）の単子音化と有声破裂音の摩揞音化を加え，唓音 化（lenition）と乎はれてきた。また。イベロ・ロマンス諸語の語頭では，流 音と音の強音化㮌向が見られ，母音間無声破裂音の弱化に対し，語頭子音强 化の典型的な耐となっている。本稿では，一般に強い位置といわれる語頭と弱 い位面といわれる語内（母音間）での子音推移の諸相を整理してみたい。

1. 音声の弱化といった場合，一般には変化前に比べて変化後の調音に要す るエネルキーが成少している場合を指すであろう。例えば，無声破裂音と有声 破裂音を比へてろると，前者の方が閉鎖が固く，閉鎖後にできる口腽・㸶頭内 の気氏が高く、さらにはその破裂が強いという点で ${ }^{1)}$ ，無声破裂音から有声破 裂音への変化は調音上の驰振と言える。なお，Escure，G．（1977）は，主とし てゲルマン藉語及びロマンス諸語のテータをもとに子音の相対的強さを次のよ うに示している。

\begin{tabular}{|c|c|c|c|c|c|c|c|}
\hline \multirow{2}{*}{ weaker } & & \multirow{2}{*}{$\frac{2}{\text { liquids }}$} & \multirow{2}{*}{$\frac{3}{\text { nasals }}$} & \multirow{2}{*}{$\begin{array}{l}\frac{4}{\text { voiced }} \\
\text { fricatives }\end{array}$} & $\frac{5}{\text { voiced stops }}$ & $\frac{6}{\text { voiceles }}$ & stronger \\
\hline & glides & & & & $\begin{array}{l}\frac{\text { voiced stops }}{\text { voiceless }} \\
\text { fricatives }\end{array}$ & \multicolumn{2}{|c|}{ stops } \\
\hline
\end{tabular}

しかし、ここで住意しなければならないのが同化現象である。例えは，英語 の looked に見られる同化による無声化（[d]>[t]）は，Escure の序列からす れは胎音化ということになる。しかし，発音調節の场所・運功を節約し，調音 をよりスムースに通んでおり，同化は明らかに爫力の節粎なのである。Jes- 
persen (1922)、の言菒を借りろなら。

：大多数の言語変化において，我々は坬立した音の篗易を諨ずるのではな く、語の中に出て来る他の音とのその特别な連結上の篗易を考蛔しなけ れはならない(pp.485-486)

というわけである。結局、母音間での無声破裂音の有声化は，前後の母音によ る声の同化であり，順行と逆行の同化が二重に行われ，連辞的には声帯の振動 が中断することなく，やはり.エネルギーの節約になっている。Escure の序列 に照らしても，また連辞面でも。この有声化は典型的弱化と言える。

次に有声破裂音の摩擦化について言うならばこれは前後の母音の開きに対 する同化であり，声道内の気流に対する抵抗は，この閉鎖の弱化によって楥和 されており，有声化同様，調音力の低下を示している。2）また，重子音（geminadas）は単子音よりも持娃時間が長く，その調音はより力強い子音であり， 従って単子音化もやはり調音の弛粰ということになる。しかし，あとで报う流 音・音に見られる単子音化は，同じ単粁とは言え破裂音の堨合と異なり， 変化前の重子音に劣らぬ强い調音を残している。従って，単子音化がそのまま 弱化ということにはならない。

さて，次の表はスペイン語における母音間破裂音の変化を示したものであるる ラテン語—古スペイン語—現代スペイン語

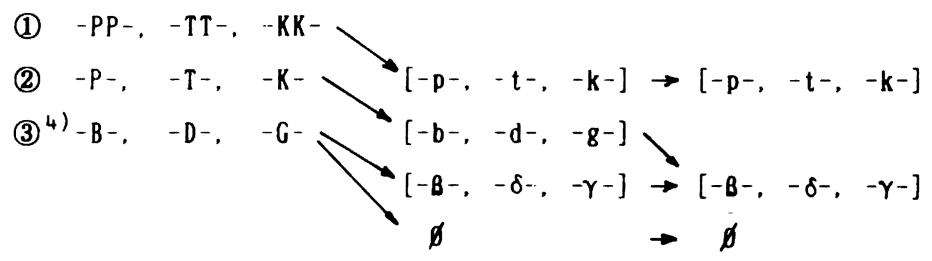

上記(1)の単子音化. (2)の有声化、(3の歷接化あるいは消失は，破裂子音の見 事な連销反応的弛示している。

一方、語頍ではその安定振りが筧える。

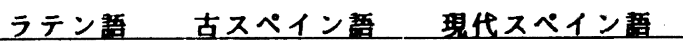

(4) $\mathrm{P}_{-}, \mathrm{T}^{-}, \mathrm{K}^{-} \rightarrow\left[\mathrm{p}^{-}, \mathrm{t}^{-}, \mathrm{K}^{-}\right] \rightarrow\left[\mathrm{p}^{-}, \mathrm{t}^{-}, \mathrm{k}^{-}\right]$

(5) B-, D-., G- $\rightarrow\left[b^{-}, d^{-}, 8^{-}\right] \rightarrow\left[b-, d^{-}, 8^{-}\right]$ 
Meyer-Lubke は Grammatik der romanischen Sprachen (1890) 1, §404の 冒頭で，「子音が最も虫い抵抗力を見せるのは語頭においてである」と述べて

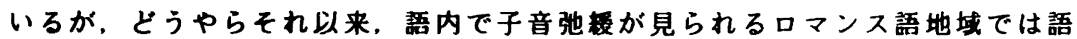
頭子音が変化が蒙らずに保持されたという見方が定着してきたようである。5) しかし，Kent，P.G.（1931）は，語頭の位固に果たして他の音節よりも音声変 化や母音消失に抵抗するような特別な（神秘的な）力があるものかと筑問を投 げかけている。そして，彼は，ラテン語で語頭音節とそれ以外の音節とで母音 の报いが異なるのは，原始イタリック語では第一音節にストレスアクセントが あったためであるとして，Cross，E．（1934）などが唱える語頭の位置に備わ った特殊な力を認めないのである。つまり，Cross が語頭の母音は無強勢でも 保たれているというのに対し, Kent（1935）は amāre p amārem の第一音節 の a は ámō, ámās, ámat, etc. によって守られているとして, Cross の資料 ・統計の不借を收掔している。

また，Malmberg（1965，p.141）に言わせると、「語頭子音の方が母音間子音 よりよく保たれているとすれは，それは語頭子音の担う情報量の多さによる」 という。つまり、語または文を情報桠造という観点から見ると, 語内・語末及 び文中・文末は語頭・文頭から予娜が可能であるのに対し，語頭・文頭は一番 予則がつかないというわけである。従って，伝䢖情報の量的力関係からすれば 語頭の担う情辂量は語中や語末より多いということになる。

その他, Jungemann（1955 pp.186-188）のように、俗ラテン語におけるスト レスアクセントの発速を根颃に，語境界をはっきり示せるようなアクセントの 存在を挙げる学者もいる。

筆者はここで語頭・語内・語末の相対的重要性を詥ずるつもりはないし，ま た語頭の不思蓄な力を弁蓄するつもりもないが，スペイン語では実懸語頭での 音堷消失・弱化が他の音節に比べてはるかに少ないことだけは礁かである。

2. Hall Jr. (1964) は. sandhi (連声) 現象及び ad '〜へ' + ferre, '通ぶ> >afferre, sub '〜の下に' + pōnere '目く'> suppōnereのような 派生形に見られる重子音化（syntactic doubling）を示す記号として/なを設 け，例えは原始ロマンス語の (et)の垉合。母音の前では /et/と，子音の前 
では/eサと記述し，語頍で考えられる音声珢境として次の 4 つを挙げている。

\begin{tabular}{|c|c|c|c|}
\hline 位置 & 変化前 & 意化镍 & \\
\hline A. 母音後 & lopátre & lobádre & 饮音化 \\
\hline B. ポーズ後 & pátre! & pádre! & \\
\hline C. 子音後 & lospátres & lospádres & 非吹音化 \\
\hline D. $/+/$ の後 & eppátres & epádres & \\
\hline
\end{tabular}

語頭の 強い位置を可能にする要素の1つに重子音化を加えたことは評価 できる。しかし、スペイン語の bravo（<PRom./pránu/) や古サルジニヤ語の gruke (<PRom./krúke/) ‘十字架’などに見られる 語頭の有声化については, 上記Aの*/lobádre/(Pre-French<PRom./illupátre/ が B，C，Dの非軟音化 例からの類推が的き/10padre/ に置き換えられたという解釈に筆者は賸成で きない。つまり、ここで問題なのは，語頭で見られる一部の有声化例が, 果た して sandhi 現象の存在を裹づける証损になり得るかという点である。

この現象で 先ず気がつくことは，p->b-， t->d-に比べて k->g-の 有声化 例が圧倒的多いことである。p->b-の例もあるにはあるが，その中にはモサ ラベ経由の語が多い。しかし，この有声化が彼らの言葉にも起こっているた め、それらを除けは $\mathrm{t}->\mathrm{d}-$ と同様，極めて敬発的（esporádico）現象と言え るだろう。なお, $k->g-の$ 場合. Corominas の Breve Diccionario Etimológico de la Lengua Castellana (1961) を調べた Wright, R. (1982) による と、語頭のCA-については中世の150語が現在無声の[k] を保ち、20語に 有声化 $[k a]>[\mathrm{ga}]$ が見られるという。この数字は率にしても決して多いとは

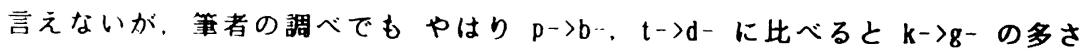
が目立っている。6)

語頭の 有声化については，Uhlenbeck の異化説，Gavel のバスク語 基屏 説. Salvador (1986) の 中和説。あるいは前述の Hall (1964) p Weinrich (1958) に見られる 類推的回復説 (analogical reintegration. analogical restoration）などが挙げられるが.しかしスペイン語における語頭破裂音は 他の子音同样相当安定しており，また問題の有声化が $\mathrm{k}$-〉g-に大きく昍って いる以上、これを、/Vp-, Vt-、Vk-/>[Vb-、Vd-、Vg-」に見られる sandhi 現象

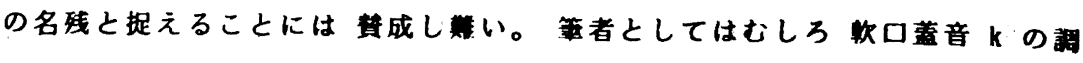


音上の特第一義的要因と考えたい。語内での有声化も，例えばイベリ ヤ半島諸語やイタリヤのトスカーナ方言においては k>g が年代的にも量的に b先行している。7) Bustos Tovar (1960，p.99）は，母音間においてk>g の 有声化が早かったのは， $\mathrm{k}$ の調音時間が長く，調音の張りが弱いことと直接関 係があるという。また，Gili Gaya (1918，p．48）によると，破裂時の呼気エ ネルギーについては / / / が一番少ないらしい。8) どうやら，/k/ が 調音面で /p, t/より驰楥的であるというのは確かなようだ。しかし，これが語頭の sandhi 現象と直接結びつくとは思えない。なぜならスペイン語の語頭では， 鳴音の強音化に見られるように sandhi 現象を許さない語境界に対するこだわ りが感じられるからである。ただ，このような傾向の中でも，/k/ は語頭・語 内に関係なくその調音的特徽を垣間見せたと考えられる。/k/の弱化の方向と しては，Escure の序列（p.1）の5に見られるように，有声化の他に gorgia

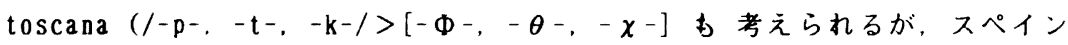
語では語内の顿向に治って有声化の道を辿ったものと推測される。/k/の調音 的特落を考えた場合，たと元語頭であっても後晩母音による逆行同化で充分説 明可能である。四に, gorgia toscana の場合もやはり/k/>[x]が先行して いる。9)

3．流音と音に入る前に，両唇破裂音を例にとり，母音間における重子音 と单子音の推移関俰（pp>p，p>b，b>日）について考えてみよう。この連鎖反応 的単䢁化で先ず問題になるのが，果たしてこれが押し連鎖 (cadena de empuje) なのかそれとも引き連鎖（cadena de tracción）なのかという点であ る。/只/と/b/の混同は既に俗ラテン語に見られ，これは当然/b/>[B] を 示すものであり ${ }^{10)}$ ．この摩䆖化が/d，8/にも及んでいたことは充分考えら れる。11)なお，弱化に対する抵抗は一般に大きい順に labiales-dentalesvelares と言われているが12)，この序列からすると俗ラテン語の/b/>[B] は 全くその逆である。ただ俗ラテン語における/岀/と/b/の輪合を考えるな らこれも領けよう。

いずれにしても，有声接 $[\beta, \delta ， \gamma]$ はあくまでも音素/b，d，g/ の異音であり，pp>p，p>b の誘発要因にはなりにくい。次に $p p>p$ が先か $p>b$ 
が先かと言えは、 Martinet（1952）は，重子音（geminadas）の頻度がそれと ペアを組む単子音のそれに匹敬するほどの言語では、話し手は無意㦈のうちに 調音に要する時間・エネルギーを減少させる㑯向が予想されるとして，有声化 誘発の第一要因にこの重子音の圧力を想定している。一方，Alarcos（1968， p. 243）は，押し連鎖と引き連镍の 2 つの可能性を示㖅するだけである。しか し，有声化が単子音化よりずっと早くから始まっているということは周知の事 実である。13）Politzer（1951）によると，北フランスの単子音化は8 世紀に なって急に增加を見るが，有声化はこれに先行する形で現われており，古くは $2 \sim 3$ 世粑の碑文に見られるラテン語の有声化につながるという。さて、こう した有声化の先行について, Martinet (1975, p. 72) は, 并別維持上, 有声化 が完了して初めて単子音化が行なわれると反詥しているが，有声化は重子音の ない言語、列えば北京官話、中世及ひ現代の英語、アルタイ㬼語、ドラウィタ 諸語などによく見られる現象であり，しかもルーマニヤ語，ダルマチャ語ある いは高地アラコン方言のように，単子音化が起こっても有声化が見られない言 語のことを考えると，重子音の存在が有声化の必要条件とは思えない。14）これ まで知り得た事実に即して判断するならば，この連銷的変化の引き金役はやは り有声化というのが妥当であろう。

また、この有声化によってできた無声破裂音の穴を重子音が単子音化するこ とによって埋めたとする槽造主羕的説明はかなり有効である。ただ、スペイン 語の特儌である開音節橉造の形成期にあって重子音の単子音化も有声化同様最 小努力の法則に通っており，原（1987，p.10）も述へてていように，軟音化は 柫造的説明と経济性の説明とが完全に平行している典型的な例と言える。

4.次に流音と音について考えてみよう。スペイン語における母音間での

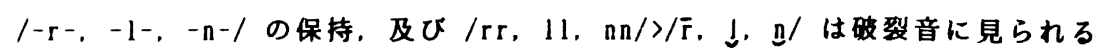
語内の弱化とは全く相反する現象である。つまり, /11/ / $/ /$ と/nn/ / / $/$ の

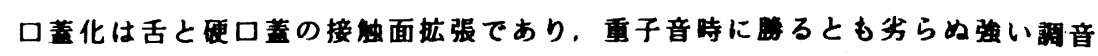
を伴っている。15) また。/rr/〉/ $/$ / は言うまでもなく著しい祭張性を帯ひたふ

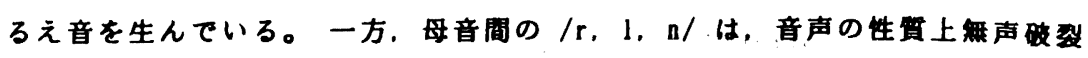
子音のように有声化するというわけにもいかず，破裂音の谒合とは亭情が䱊 
なっている。ただ、1とnが yod を従えた場合, / / y / / / I, /ny $/ / \mathrm{n} /$ のよう にロ蓋化が起こり．|yでは/11/>/1/ との混同を避けて/1y/>/1/ //3/まで 進んでいる。また,/r/の場合は LACTARIA>laytayra>lechera のように,/r/ は口蔥化しにくいみたいで，音位転倒によって/r/の前に 飛び出している。 䊅局，yod が後続する場合を除くと，/1，n，r/は音間であっても弱まるこ となく保持されるのである。このような安定して動きにくい単子音の/1, 几 $\mathrm{r} /$ /対し，重子音の / r r / はそれまでの長い持続時間からふるえ音 $/ \bar{r} /$ へと 質的変化を行ない，/11，nn/も yod による口蓋化に做うかのように質的変化

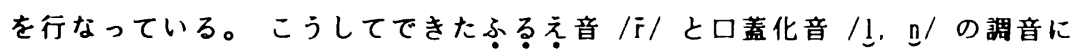
要するエネルギーは重子音時のそれを受け継いでおり，破裂子音に見られる弱 化とはだいぶ異なっている。さらに語頭の $/ \mathrm{r}-/>/ \overline{\mathrm{r}}-/$ に至っては，明らかに 虺音化であり，これをイベリヤ半島諸語の中で見ると，語頭における流音・县 音の强音化㑯向は一層はっきりしてくる。

\begin{tabular}{|c|c|c|c|c|c|c|c|c|c|c|}
\hline \multirow[b]{2}{*}{ español } & \multicolumn{3}{|c|}{$\mathrm{R}-/ \mathrm{L}-/ \mathrm{N}-$} & \multicolumn{2}{|c|}{$\mathrm{RR} / \mathrm{LL} / \mathrm{NN}$} & \multicolumn{3}{|c|}{$-\mathrm{R}-/-\mathrm{L}-/-\mathrm{N}-$} & \multicolumn{2}{|c|}{$L Y / N Y$} \\
\hline & $\overline{\mathrm{r}}$ & 1 & $\mathrm{n}$ & $\overline{\mathbf{r}}$ & 1 & $r$ & 1 & $\mathrm{n}$ & $\mathrm{x}$ & $\underline{n}$ \\
\hline catalán & $\bar{r}$ & 1 & $\mathrm{n}$ & $\overline{\mathbf{r}}$ & 1 & $r$ & 1 & $\mathrm{n}$ & 1 & n \\
\hline león & $\overline{\mathrm{r}}$ & 1 & $\underline{n}$ & $\tilde{\mathbf{r}}$ & $1 n$ & $r$ & 1 & $n$ & $\mathrm{y}$ & $\underline{\text { n }}$ \\
\hline gallego & $\overline{\mathrm{r}}$ & 1 & $\mathrm{n}$ & $\tilde{\mathbf{r}}$ & $1 \mathrm{n}$ & $r$ & $\phi$ & $\phi$ & 1 & n \\
\hline
\end{tabular}

Straka（1965，§5）は，イベロ・ロマンス諸語に見られるこれらの語頭の ロ真化について，語頭はたとえアクセントがなくても，強い位置ゆえ舌と硬口 蓋の接面拡大は理解できるという。しかし，スペイン語では $/ 1-/ と / \mathrm{n}-1$ はなせかロ蓋化していない。Martinet によれは. /p1-, f1-, cl-/の口蓋化

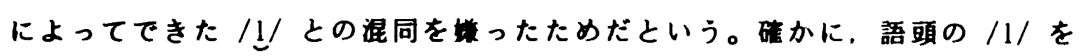
口䓰化しているカタルーニ+語では/pl-, fl-, cl-/は変化せず，レオン方 言です/p1-, 11-, c1-/は[汇]に変わってその对立は保たれている。それに

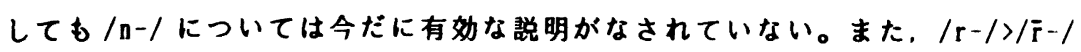
について、Granda (1966，p.89）は，「外破の位国としては弱すきる音来を胎 めようとする音简棈造の発䢖」によると説明する。

いずれにせよ，流音と音の埸合、イベロ・ロマンス諸䙵全体の流れとして。 
語内での安定化。語頭での強音化㑯向は否定できないだろう。

ところで. Martinet（1952）は，やはり強い調音を持つ重子音の/11，rr， $\mathrm{nn} /$ が、語頭の强い単子音と合流したとする解釈を破裂音にも息用するが、こ

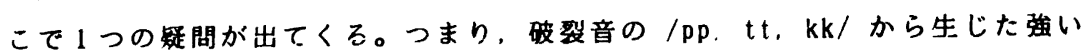
調音の単子音が最終的には語頭の単子音と合流するが，その際，語頭の単子音 は果たして重子音から生じた単子音ほど强化されていたのかどうか？Veiga， A. (1988) にしても，/pp， tt，kk/に由来する初期の单子音 [ $\left.p^{+}, t^{+}, k^{+}\right]$ を sonidos hipertensos とまで名づけているが，これと合流する語頭の/pt一。 とは Martinet も認めている。結局, 破裂音の重子音/pp, $\mathrm{t} t$, kk/ が単子音 化する時に，tense の・/P，T，K/を想定したところに，無理があるように思 える。/ $\mathrm{r} r ， 11, \mathrm{nn} />/ \bar{r}, 1, n /$ は明らかに強い調音を保っているのに対し， $/ p p, t \mathrm{t}, \mathrm{kk} /$ は重子音の弱化であり，調音の独さの点でもともと方向が異な

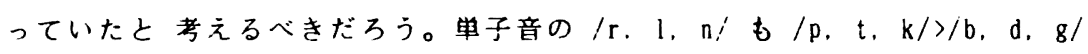

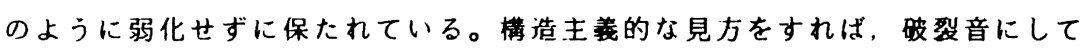
も，流音・音にしても，重子音と単子音の対立関倸は見事に保たれている。 単純化あるいは単子音化という意味では確かに同じ方向を目指している。しか し、この単純化は必ずしも弱化ということではない。軟音化は主に破裂音の頒 向であり，流音と音の動きはこの弱化に与するものではない。もっとも，カ リシヤ方言のような弱化の例もある：/11, nn/:/1, n/, / $1, \mathrm{n} />\phi_{0}$

5.今度は摩擭音の/ss, $\mathrm{s} /$ と/f/ の変化を見てみよう。/s/は，母音 間では破裂音と同様有声化し! ${ }^{16)} / \mathrm{ss} /$ は単子音化している。ただし，重子音の

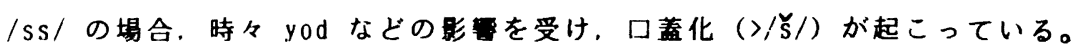

: QUASSIARE>quexar $>q u e j a r$. RUSSE $0>r 0 \times 0>$ rojo, BASSUS $>* B A S S I A R E>b a-$ jar, etc. ${ }^{17)}$

しかし，一見口蓋化しゃすく思えるこの/s/が syでは音位転倒を計り， ssyとの対立を保っているように見える。

: BASIU>beso, SEGUSIU>sebueso, etc. ${ }^{18)}$

このように，母音間では破裂音同梂饮音化が起こっていろが，語頭では一般 
には/s/を保持している。

: SALIRE>Salir, SALTU>soto, SITE>sed, etc.

ただ。/sー/の場合にも語内の重子音の推移に呼応するかのように口盖化が よく見られる。

: SAPONE>xabón>jabón, SEPiA>xibia>jibia, SOCU>xugo>jugo, SYRINGA> xiringa>jeringa, etc. ${ }^{19)}$

この口蓋化の要因として、これまでに次のようなものが唱えられてきた。

(1)アラビヤ語基層説 20)

(2) 主に硬口蓋母音・蛞盖母音による同化

(3) 音需学的類做 211

(4) 対立の機能奻率（機能負担量）の低さ22)

(5)語頭における/公/の煩度が極めて低いことから，表現奻果をねらって の增殖㑯向 ${ }^{23)}$

(6)語頭での謂音強化頓向 ${ }^{24)}$

この現象は意外に椱嚾で、詳細は阿部(1986)を参照されたいが、ここで注目 して欲しいのが (6)である。/s/>/š/はレオン方言. ガリシャ方言.カタルー ニャ諨でも知られており，Castro，A．（1914，p.102）は，レオン方言の/1-。 n-/のロ盖化, 及びタルーニャ語の/1-/ の口盖化との類似性を早くから指 澫している。また。Alonso，A，（1947，p．10）は，特に昔の音声状態では語頭 は㤝化に有利な位䠄だと言う。同様に, Nandris（1952, p. 139）は, ロマンス 語における/1-、n-、s-/の口盖化は語頭という位固のお险だと述べている。

結局、スペイン語の埸合，語頭での/s/の口盖化は音䫓法則として一般化 するには至らなかったものの，イベロ・ロマンス諸語の複雑な諸相の中にその 㑯向が窟えるような気がする。25)

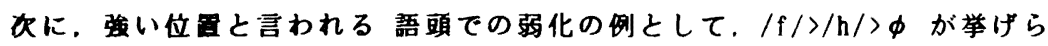
れる。さて，その要因としてバスク語基層説を支持する学者は以前多いが，こ れについて筆者は既に何度か反論しており，詳しくは阿部（1976，1988）参 照されたい。筆者は，半島・中南米における[Ф]の勢い，半島の俗ラテン語

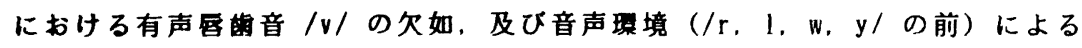
/f/の保持などから考えて，俗ラテン語の/f/の異音的存在として両唇摩撩 


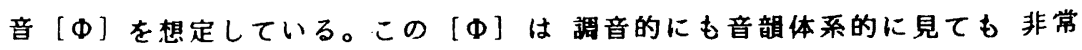
に不安定な音である。従って，斥音の前ではその屁によって一抟開かれ，や がて消失したが，閉じた子音や半子音の後ではやはりその据害を受けて[Ф] は閉じられ，その不安定さが払拭されたと考えられる。/1，r，w，y/の前で の保持について，Granda (1966, pp.12-126) は。もし/f/が消失した場合。 次は/1，r，w，y/が強い位置に立って強化されることになり，/f／の消失は 無因な推移だと言う。それなら初めから/f/を保持した方がよいと説明して いる。彼に言わせると、これは予防的強化（reforzamiento preventivo）なの だそうである。しかし，そうは言っても・/f/の弱化は誰の目にも明らかであ

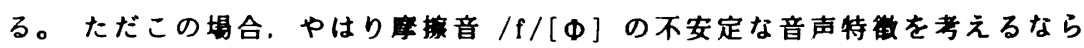
ば、語頭での消失も領けよう。

なお，母音間では破裂音と同様有声化が起こっている。26)

: PROFECTU>provecho, TRIFOLIU>trébol, etc.

しかし，母音間の/f/はもともと少なく、そのほもんどが 複合語で。その 意誏がある埸合は語頭の扱いを受けているようである。

: REFACERE >rehacer, CANNAFERULIA>cañaherla, SUBFUMARE >Sahumar, etc.

また，次に挙げる例はその迷いからくる摇れを示すものかもしれない。

: REFUSARE $>$ rebusar, rehusar, CO(N)FECTARE >cobechar, cohechar, etc.

その他、本来ならば二重擢字(ff)についても能れなけれはならないのだが， 音価の解釈が觀しく，推測の域を出ないので今回は扱わないことにする。27)

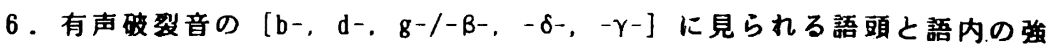
い異音と弱い異音の関係はyod 後）には破裂音を、語内（母音間）には度揞音を圆く㑯向がここです見られる というわけである。 
[b, d, g]

[gw]

$[\overline{\mathrm{dj}}]$ $[\beta, \delta, \gamma]$

[w]

$[\mathrm{j}]$

語頍：yo ['djo], yeso ['djeso], huerfano ['gwerfano], gueno (<bueno), gueso (<hueso), etc. ${ }^{28)}$

語内: mayo ['majo], agua ['awa, 'arwa], antiguo [an'tiwo], aguardar [amar'sar], etc. ${ }^{29)}$

子音後: lengua [ ${ }^{\text {lengwa }}$, MInUARE $>$ menguar, ciruela $>$ cirguela, un hueso [un'gweso], etc. ${ }^{30}$ )

\section{7. 䊅垥}

(1)筆者は語頭に神秘的力を認めるものではないが，スペイン語に限って言 うならは，語頭は是いなく安定した強い位湎と言えるだろう。

(2) 母音間において重子音と単子音が混同を避けるため,一定の距離を保ち ながら推移しており。しかも重子音は単杶化（単子音化）しているという点で は，破裂音も流音・音もその推移㑯向は確かに一致している。しかし，母音 間での調音的弱化という意味では，ガリシヤ方言を除くと，破裂音と流音・舟 音とでは方向が異なる。

(3)破裂音の明らかな弱化㑯向の中で，破裂音の重子音が初期の段陼であ れ，強い調音を保持したと想定するには無理がある。つまり，語頭の/p-。

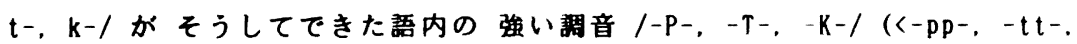
-kk-) ほど強かったという証执はないのである。結局, Martinetの説では， あくまでも重子音の圧力及び破致音と鳴音の並行的推移が軟音化の前提になっ ているために、このような矛盾がでてくる。筆者としては，破致音の炏音化の 㴽因として有声化を传先したい。

(4)浯頭での有声化 $(/ \mathrm{k}-/ / / \mathrm{g}-/), / \mathrm{f} /$ の抲化・消失，及ひ流音・音の推

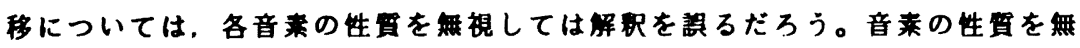

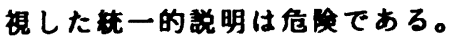


拄

1) 服部 (1965) pp. 83-84：Schubiger（1973） pp.74-75; Lass, R. (1971) pp. 25-29

2) Dekeyser, X. (1978) p. 112; Lass, R. (1971) p. 25; Grammont (1971)

3) Oftedal, Magne (1985) p. 45

4）形態素内の有声の重子音（bb，dd，gg）もあるにはあるが非常にまれな ため，この表からは省いた：ABBATE>esp. abad：IN-ADDIT>enade>añade

5) Ha ll, R.A. (1964) p.551

6) 阿部 (1989)

7) Wanner \& Cravens (1980) pp.343-344; Barbarino (1981) p. 138; Bustos Tovar (1960) p.99; Grandgent (1962) §257; Politzer (1955) pp.7173

8) Pensado Ruiz, C. (1984) p. 184: Escure (1977) p.62 n.11; ただし, Straka（1964）のように調音エネルギーの少ない唇音が一番不安定であ るという学者もいる。

9) Izzo (1972)

10) Sturtevant (1968) §148-155

11) Pensado Ruiz, C. (1984) pp. 186-188

12) Lass, R. (1971) pp. 22-23; Pensado Ruiz, C. (1984) p. 183: 古英語. テンマーク語、ギリシャ語、サンスクリット、チェコ語、モンコル語な どでは饮口盖音 /g/が弱化に対する抵抗が一番弱い。

13) 阿部 (1981); Pensado Ruiz, C. (1984) pp. 216-219

14) Pensado Ruiz, C. (1984) p. 215

15) Straka (1965) §5

16) Ariza. M. (1989) D.131: CAUSA $>[$ koza] $>$ cosa. MENSA $>$ [mesa] $>[$ meza] $>$ mesa, etc.

17) 阿部 (1986) p. 101

18) Ariza, M. (1989) p. 131

19)阿部 (1986)

20) Menéndez Pidal (1968) §37.2b, 2c; Martínez Alvarez (1978) 
21) Espinosa, A.M. (1930) § 151 pp. 182-183

22) Jungemann (1955) pp. 90-94

23) Michelena, L. (1975)

24) Alonso, A. (1947); Granda Gutiérrez (1966)

25）阿部 (1986) p. 102 .

26）阿部（1988） p. 4

27) Allen, J.H. D. (1964); Veiga, A. (1988)

28）原 (1989) p. 78; Malmberg (1952)

29) Navarro Tomás (1970) §127

30) Malmberg (1952)

\section{参考文献}

回部三男 (1976)：F>h とバスク基層説. Hispánica 20.18-35

(1981): イベリヤ半島における 有声化とケルト語基層説について, ロマンス語研究13・14.70-85

(1986): 古スペイン語における語頭 /s/ の口盖音化について 東海 大学教養学部紀要 17.95-105

（1988）: 再び F/h とバスク語基層説. Hispánica 32.1-16

(1989): スペイン語における語頭子音 $/ \mathrm{k}-/$ の有声化について. ス ペイン語学研究 4.1-15

Alarcos Llorach, E. (1954): Resultados de $G^{e}$ i en la Península. Archi vum 4. 330-342

\section{(1968): Fonología española. Madrid: Gredos}

Allen. J. (1964): Tense/Lax in Castilian Spanish. Word 20.295-321

Alonso. A. (1947): Trueques de sibilantes en antiguo español. NRFH 1. $1-12$

Ariza, M. (1989): Manual de fonología historica del español. Madrid: Sintesis

Barbarino, J.L. (1981): Latin and Romance Intervocalic stops. Madrid: José Porrúa Turanzas S. A. 
Bichakjian, B.H. (1977): Romance Lenition. RPh 31.196-203

Blaylock, C. (1967-1968): Latin L-, -LL- in the Hispanic Dialects:

Retroflexion and Lenition. 패 21.392-409

Bustos Tovar, E. (1960): Estudios sobre asimilación y disimilación en

el íbero románico. Madrid: C.S.I.C.

Castro, A. (1914): Reseña a la Gramática Historica de Hanssen. RFE 1. $97-103$ y $181-184$

Catalán D. (1954): Resultados ápico-palatales y dorso-palatales de $-L L-,-N^{-}$, y de LL- $(<L-), N^{-}\left(<N^{-}\right)$. RFE 38. 1-44

Corbett. N. (1971): Reconstructing the Diachronic. Phonology of Romance. $\underline{\mathrm{RPh}} 24.273-290$

Cross, E. (1934): The Latin Initial Syllable in the Romance Languages. PMLA 48.994-1004

Dekeyser, X. (1978): Some Considerations on Voicing with Special Reference to Spirants in English and Dutch. Trends in Linguistics 4. 99-121 (Mouton)

Di Pietro. R. (1966): Juncture and the Preservation of Voiceless Stops in West Romance. Orbis 15.68-72

Escure, G. (1977): Hierarchies and Phonological Weakening. Lingua 43. $55-64$

Espinoza. A.M. (1930): Estudios sobre el español en Nuevo Méjico. BDH 1. $23-313$

Galmés de Fuentes. A. (1983): Dialectología mozárabe. Madrid: Gredos Gili Gaya, C. (1918): Algunas observaciones sobre la explosión de las oclusivas sordas. RFE 5. 45-49

González 0llé, F. (1973): La sonorización de las consonantes sordas iniciales en vascuence y en romance y la neutralización de $\mathrm{k}-/ \mathrm{g}$ en español. Archivum 22.253-274

Grammont. M. (1971): Traité de phonétique. Paris: Delagrave Granda Gutiérrez, G. (1966): La estructura silábica del dominio ibero- 
rrománico. Madrid: C.S.I.C.

Grandgent. Charles H. (1962): An Introduction to Vulgar Latin. New York: Hafner

Graur. A. (1929): Les consonnes géminees en latin. Paris: Champion Ha11, R. A. (1940): The Papal States in Italian Linguistic History. Language 19.125-140

(1964): Initial Consonants and Syntactic Doubling in West Romance. Language 40.551-556

(1975): La non-Jenizione nella Romània occidentale. RPh 28. $530-535$

原誠 (1987)： スペイン語通時音腤論の二大問題（上）東京外国語大学猃

集 37.1-25

一 (1988): スペイン語通時音腤論の二大問題（中）東京外国語大学論

集 $38.35-58$

(1989): スペイン語通時音竩論の二大問題 (下) 東京外国語大学論 集 39.73-106

服部四郎 (1969)：音声学. 東京：岩波夆店

Haudricourt, A. \& Juilland. A. (1970): Essai pour une histoire structurale du phonétisme français. The Hague: Mouton

Izzo, H.J. (1972): Tuscan and Etruscan. Toronto-Buffalo: University of Toronto Press

Jespersen. 0. (1922): Languag: its Nature, Development and Origin. London（「言語」市河・神保訳 1956 岩波毒忘）

Jungemann, F.H. (1955): La teoría del sustrato y los dialectos hispano-romances y gascones. Madrid: Gredos

Kent, P.G. (1931): The Alleged Strength of the Initial Syllable. Language $7.179-189$

(1935): Again the Initial Syllable. Language 11.151-152

Lass, R. (1971): Boundaries as Obstruents: 0ld English Voicing Assimilation and Universal Strength Hierarchies. Journal of Linguis- 
tics 7. 15-30

Lausberg. H. (1965): Linguistica románica. Madrid: Gredos

Lloyd, P.M. (1987): From Latin to Spanish. Filadelfia: American Philosophical Society

Malmberg. B. (1952): Occlusion et s⿱丷⿹弔irance dans le systeme consonantique de l'espagnol. Mélanges de Philologie Romane offerts à $M$. Karl. Michaelsson. pp. 356-365. Lund

- (1962): La notion de force et les changements phonétiques.

SL $16.38-44$

- (1965): Estudios de fonética hispánica. Madrid: C.S.l.C.

Martinet. A. (1952): Celtic Lenition and Western Romance Consonants.

Language 28. 192-217

(1975): Evolution des langues et reconstruction. Presse Universitaires de France

Martínez Alvarez. J. (1978): Acerca de la palatalización de/s/ en español. Estudios of recidos a E. Alarcos 3. 221-236

Meillet. A. \& Vendryes. J. (1924): Traité de grammaire comparée des langues classiques. Paris: Champion

Menéndez Pidal. R. (1968): Orígenes del español. Madrid: Espasa-Calpe Uichelena, L. (1975): Distribución defectiva y evolución fonológica.

Studia hispanica in honorem $R$. Lapesa 3.337-349. Madrid

Navarro Tomás. T. (1918): Diferencias de duración de las consonantes españolas. RFE $5.367-393$

(1970): Manual de pronunciación española Madrid: C.S.I.C.

Nandris. 0. (1952): Les palatalisations romanes. Orbis 1.136-145

oftedal. M. (1985): Lenition in Celtic and Insular Spanish. 0slo: Universitetsforlaget

Pensado Ruiz. C. (1984): Cronología relativa del castellano. Salamanca: Universidad de Salamanca

Pérez, Jośé I. (1982): "Observaciones en torno a la desaparición de la 
-N- inervocálica en gallego. Verba 9.201-213

Politzer, R.L. (1951): On the Chronology of the Simplification of Geminates in Northern France. MLN 66.527-531

(1955): Latin Lenition and Italian Consonants. Ceneral Lin-

guistics 1.70-78

Rodríguez Castellano, L. (1975): Palatalización de la L inicial en la Asturias de habla gallega. Verba 2.137-149

Salvador, G. (1986): Neutralización de G-/K- en español. Estudios dialectologicos, pp. 152-167

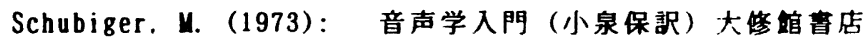

Straka. G. (1964): L'évolution phonetique du latin au frança is sous l'effet de l'énergie et de la faiblesse articulatoires. TraliLi 2. $17-98$

(1965): Naissance et disparition des consonnes palatales dans l'évolution du latin au français. Tralili 3.117-167

Sturtevant. E.H. (1968): The Pronunciaticn of Greek and Latin. Groningen: Bouma's Boekhuis N.V.

Torreblanca, M. (1988): La palatalización de l-inicial latina en catalán y leonés. Homenaje a A. Zamora Vicente 1.289-297. Madrid: Castalia

Veiga. A. (1988): El rasgo fonético tensión y los procesos protohispánicos de lenición consonántica. Actas del 1 Congreso Internacional de Historia de la Lengua Española 1.193-206, Madrid: Arco/Libros

Manner, D. Cravens, Tomas D. (1980): Early Intervocalic Voicing in Tuscan. Current Issues in Linguistic Theory 14.339-347

Wartburg. W. (1971): La fragmentación linguistica de la Romania. Madrid: Gredos

Weinrich. H. (1958): Phonologische Studien zur romanischen Sprachgeschichte. Munster: Äschendorffsche Verlags Buchhandlung 
Wright. R. (1982): Late Latin and Early Romance in Spain and Carolingian France. Great Britain: Francis Cairns

Posición inicial y interior de palabra en español

por Mitsuo ABE

No creo que haya una fuerza mistica en posición inicial de palabra. Pero al considerar los cambios consonánticos del español, nos damos cuenta de la gran estabilidad o reforzamiento fonologicos de las consonantes iniciales de palabra.

En el caso de las oclusivas, la sonorización y la degeminación indican el debilitamiento de fuerzas articulatorias. Al simplificarse las geminadas sonantes, por el contrario. tendieron a sustituir su mayor duración por una mayor zona de contacto de la lengua contra el paladar, sin perder su intensidad articulatoria anterior. Además en el caso de las sonantes iberorrománicas. nos parece indudable que las simples /1-. $n-, r-/$ iniciales de palabra han tenido una tendencia a reforzar su articulación hasta el grado de la enérgica articulación de los resultados de la degeminación.

En la tendencia al debilitamiento articulatorio de las oclusivas. nos parece poco significante suponer el grado sumo de tensión articulatoria para los resultados de las geminadas recién simplificadas. No hay ninguna prueba directa, como lo observa Martinet, de que las oclusivas iniciales de palabra hayan sido reforzadas hasta el extremo de resultar identicas a las fuertes correspondientes a las geminadas latinas. 
Y para una mejor explicación de los cambios fonológicos, hay que tener en cuenta las características de los sonidos. Por ejemplo, la sonorización de $/ \mathrm{k}-/>/ \mathrm{g}-/$ inicial de palabra podría explicarse como relacionada directamente con las caracteristicas articulatorias de / $/$. esto es. con una menor tensión articulatoria de la consonante velar respecto de la labial o la dental. 